\title{
PARTISIPASI MASYARAKAT DALAM MEWUJUDKAN E-KTP DI KECAMATAN KEPULAUAN SANGKARANG KOTA MAKASSAR
}

\author{
Participation in Realizing E-KTP in the District of Sangkarang Islands Makassar City \\ Kurniati $^{1}$, Andi Rasjid Pananrangi ${ }^{2}$, Syamsul Bahri ${ }^{2}$ \\ ${ }^{1}$ Magister Ilmu Administrasi Negara, Program Pascasarjana, Universitas Bosowa \\ ${ }^{2}$ Program Studi Ilmu Administrasi Negara, Program Pascasarjana, Universitas Bosowa \\ Email: kurniatibarlom@gmail.com \\ Diterima: 25 Agustus 2020 \\ Dipublikasikan: 07 Desember 2020
}

\begin{abstract}
ABSTRAK
Tujuan penelitian dengan maksud menggambarkan dan menginterprestasikan masalah yang berkaitan dengan partsipasi masyarakat dalam mewujudkan e-KTP di kecamatan Kepulauan Sangkarrang. Data diperoleh dengan menggunakan teknik pengumpulan data dengan cara observasi, wawancara, studi kepustakaan, penelusuran data online, dan dokumentasi. Teknik analisis data pada penelitian ini dilakukan secara cermat sesuai dengan metode penelitian ilmiah berdasarkan konsep analisis data yang digunakan pada metode penelitian kualitatif. Hasil penelitian menunjukkanProses pengurusan pembuatan e-KTP di kecamatan Kepulauan Sangkarrang kota Makassar dilakukan dengan berdasar kepada beberapa indikator. Para pegawai sebagai implementator melaksanakannya dalam tiga konsep yaitu landasan hukum, sosialisasi, dan pendanaan. Secara garis besar ketiga hal tersebut berdasarkan hasil penelitian menunjukkan bahwa semua proses tersebut berjalan dengan baik dan tidak terdapat kendala yang berarti kecuali pendanaan. Sementara itu faktor-faktor yang mempengaruhi pembuatan e-KTP di kecamatan Kepulauan Sangkarrang yang berdampak kepada partsipasi masyarakat adalah komunikasi, sumber daya, sarana dan prasarana dan kondisi geografis. Pada kegiatan komunikasi antara pemerintah sebagai penyelenggara dengan masyarakat yang ada di kecamatan Kepulauan Sangkarrang sudah dilakukan dengan baik. Hal yang sama juga dengan ketersediaan sumber daya dimana berada pada posisi yang cukup baik. Sementara itu yang cukup berpengaruh dalam mewujudkan partisipasi masyarakat yang ada di kecamatan Kepulauan Sangkarrang dalam pembuatan e-KTP adalah persoalan sarana dan prasarana serta kondisi geografis. Persoalan sarana dan prasarana dalam hal ini adalah jaringan listrik dan internet yang sering bermasalah bahkan di kecamatan ini, jaringan listrik untuk umum hanya dinyalakan pada malam hari. Sementara itu kondisi geografis daerah ini yang dibatasi laut antara pulau yang satu dengan pulau lainnya yang sangat berpengaruh. Hal ini dikarenakan transportasi mereka ketika akan mengurus ke kantor kecamatan menggunakan perahu atau kapal nelayan, yang sewaktu-waktu jika cuaca kurang bagus sangat berisiko.
\end{abstract}

Kata Kunci: Partisipasi Masyarakat, Administrasi Kependudukan, Kualitas Pelayanan, Sangkarang, Makassar

\section{ABSTRACT}

The aim of this research is to describe and interpret those related to community participation in realizing e-KTP in Sangkarrang Islands district. The data were obtained by using data analysis techniques by means of observation, interviews, literature study, online data search, and documentation. The data analysis technique in this study was carried out carefully with scientific research methods based on the concept of data analysis used in qualitative research methods. The results showed that the process of making e-KTP in the Sangkarrang Islands district, Makassar city was carried out based on several indicators. The employees as implementers carry it out in three basic concepts, which are law, socialization, and concerts. Broadly speaking, the three things are based on the results of the research showing that all these processes are running well and nothing is excluded. Meanwhile, the factors that influence the making of $e$-KTPs in the Sangkarrang Islands district that have an impact on community participation are communication, resources, facilities and geographical conditions. Communication activities between the government as the organizer and the people in the Sangkarrang Islands district have been carried out well. This is also same as the resources which are in a fairly good position. Meanwhile, what is influential in realizing community participation in the Sangkarrang Islands district in making e-KTP is the problem of facilities and infrastructure as well as geographical conditions. The problem of facilities and infrastructure in this case is the electricity and internet networks which are often problematic. Even in this district, the public electricity network is only turned on at night. Meanwhile, the geographical conditions of this area limited between one island and another are very influential. This is because their transportation when they go to the district office is by boat or fishing boat, which sometimes when the weather is not good is very risky

Keywords: Society participation, Population Administration, Service Quality, Sangkarang, Makassar

\section{PENDAHULUAN}

Aparatur Sipil Negara (ASN) merupakan aset Pelaksanaan pembangunan nasional merupakan upaya sistematis yang dilakukan pemerintah dalam upaya perbaikan dan pertumbuhan untuk mencapai kesejahtaraan masyarakat. Keberhasilan pembangunan tidak lepas dari kecakapan kemampuan negara. Dengan demikian kelancaran penyelenggaraan pembangunan nasional tergantung pada kemampuan dan aparatur pemerintah serta kebijakankebijakan apa yang akan diambil tergantung dari pimpinan hingga unsur pelaksana 
yang melaksanakan langsung kebijakan dalam hal ini berperan sangat penting.

Partisipasi masyarakat merupakan hak dan kewajiban seorang Warga Negara untuk memberikan kontribusinya kepada pencapaian tujuan kelompok sehingga mereka diberikan kesempatan untuk ikut serta dalam pembangunan menyumbangkan inisiatif dan kreatifitasnya. Partisipasi masyarakat adalah keterlibatan mental dan emosional individu dalam situasi kelompok yang mendorongnya memberikan sumbangan terhadap tujuan kelompok serta membagi tanggungjawab bersama. Adisasmita (2006:38) mengemukakan bahwa partisipasi masyarakat dapat didefinisikan sebagai keterlibatan dan pelibatan anggota masyarakat dalam pembangunan, meliputi kegiatan dalam perencanaan dan pelaksanaan pembangunan. Adi Isbandi (2007:27) menyatakan partisipasi masyarakat adalah keikutsertaan masyarakat dalam proses pengidentifikasian masalah dan potensi yang ada di masyarakat, pemilihan dan pengambilan keputusan tentang alternatif solusi untuk menangani masalah, pelaksanaan upaya mengatasi masalah, dan keterlibatan masyarakat dalam proses mengevaluasi perubahan yang terjadi. Jadi partisipasi masyarakat yang dimaksud sendiri itu ialah merupakan wujud tingkah laku masyarakat secara nyata dalam suatu keterlibatan program untuk pembangunan masyarakat itu sendiri.

Pendaftaran penduduk pada hakekatnya merupakan pencatatan biodata penduduk, pencatatan atas pelaporan peristiwa kependudukan dan pendataan penduduk rentan serta penerbitan dokumen kependudukan berupa kartu identitas dan surat keterangan kependudukan. Dalam pelayanan pendaftaran penduduk, masalah yang dihadapi sering terjadi pemberian data individu yang tidak sesuai dengan data sesungguhnya, dan tidak ditunjang dengan dokumen lain. Akibat dari permasalahan ini, data individu menjadi kurang akurat dan masyarakat mengalami kesulitan dalam pelayanan publik lainnya, seperti pelayanan kesehatan, pelayanan perbankan, permasalahan sosial dan lain-lain.

Perkembangan teknologi informasi maupun komunikasi menghasilkan manfaat positif bagi kehidupan manusia dan memberikan banyak kemudahan, seperti kemudahan dalam memperoleh informasi dan kemudahan bertransaksi. Perkembangan teknologi informasi dan komunikasi juga dapat membantu manusia dalam menjalankan aktivitasnya, karena segala kegiatan dapat dilakukan dengan cepat, murah, dan tepat, sehingga produktivitas kerja akan meningkat. Perkembangan teknologi informasi dan komunikasi memperlihatkan bermunculannya berbagai jenis kegiatan yang berbasis pada teknologi ini, seperti dalam dunia pemerintahan $(e-$ government), yang didalamnya memiliki program seperti dalam bidang pemerintah (e-KTP), pendidikan (eeducation, e-learning), kesehatan, (e-medicine, elaboratory), dan lainnya, yang kesemuanya itu berbasiskan elektronik.

Terwujudnya good governance merupakan cita-cita luhur seluruh masyarakat di dunia termasuk di Indonesia, good governance atau pemerintahan yang baik menekankan pada asas-asas akuntabilitas, transparansi, partisipasi, efektivitas dan efisiensi. Untuk mewujudkan kelima pilar tersebut, dilakukan berbagai metode sebagai alatnya yaitu dengan penciptaan E-government atau pemerintahan berbasis teknologi informasi yang memanfaatkan kemajuan komunikasi dan informasi pada berbagai aspek kehidupan.

Salah satu cara yang kini ditempuh oleh pemerintah pusat Indonesia adalah inovasi pelayanan publik dengan metode E-government yaitu dengan penerapan e-KTP atau KTP berbasis sistem informasi. e-KTP merupakan cara jitu yang akan ditempuh oleh pemerintah dengan membangun database kependudukan secara nasional untuk memberikan identitas kepada masyarakat dengan menggunakan sistem biometric yang ada didalamnya. Setiap pemilik e-KTP dapat terhubung ke dalam satu database nasional, sehingga setiap penduduk hanya memerlukan satu KTP saja. E-KTP adalah dokumen kependudukan yang memuat sistem keamanan atau pengendalian diri dari sisi administrasi ataupun teknologi informasi dengan berbasis pada database kependudukan nasional. e-KTP dilengkapi dengan fitur penggunaan sidik jari, dalam penggunaan sidik jari e-KTP lebih canggih dari yang selama ini diterapkan untuk SIM (Surat Ijin Mengemudi). e -KTP menjadi sangat penting dikarenakan dalam beberapa tahun terakhir ini, masyarakat Indonesia dihadapkan pada beberapa permasalahan yang berkaitan dengan lemahnya sistem Administrasi Kependudukan di Indonesia (Achyar dkk, 2019).

Diantara masalah tersebut adalah mulai dari orang yang meninggal yang masih mendapatkan hak suara ataupun kepemilikan KTP ganda yang menyebabkan permasalahan pada kepemilikan suara ganda dalam Pemilu Legislatif, Pemilu Presiden maupun Pemilukada, penerapan asuransi kesehatan bagi rakyat miskin yang tidak sampai sasaran karena penjelasan profesi di KTP yang kurang detail sampai dengan penyalahgunaan KTP sebagai alat bagi para penjahat dan teroris yang bisa jadi lebih leluasa berganti identitas.

Pemerintah melalui Kemendagri telah menerapkan kebijakan program e-KTP berdasarkan UU No 23 Tahun 2006 dan Peraturan Presiden No 67 Tahun 2011 tentang Perubahan Kedua atas Peraturan Presiden No 35 Tahun 2010 tentang Penerapan KTP berbasis Nomor Induk Kependudukan secara Nasional.

Kebijakan tersebut bertujuan untuk menciptakan administrasi yang tertib sesuai dengan peraturan yang telah ditetapkan dan untuk mencegah dampak negatif dari penggunaan KTP manual. Seperti mencegah dan menutup peluang adanya KTP ganda yang selama ini banyak disalah gunakan oleh masyarakat yang dapat menyebabkan kerugian bagi negara. e-KTP merupakan sistem kependudukan terbaru yang sudah diterapkan oleh pemerintah, hal ini sesuai dengan amanat UndangUndang No. 23 Tahun 2006 tentang Administrasi Kependudukan, dimana pada pasal 101 huruf a, undangundang tersebut dijelaskan bahwa memerintahkan kepada 
pemerintah untuk memberikan NIK kepada setiap penduduk paling lambat tahun 2011.

Selain itu, undang-undang ini juga diperkuat dengan Peraturan Presiden No. 26 Tahun 2009 tentang Penerapan KTP berbasis NIK secara nasional. Implementasi program e-KTP secara nasional ini sudah diluncurkan sejak tahun 2009 dengan menjadikan 6 Kabupaten/Kota sebagai pilot project e-KTP. Keenam Kabupaten/Kota tersebut adalah Padang, Makasar, Yogyakarta, Denpasar, Cirebon dan Bali. Implemntasi program nasional e-KTP merupakan amanat dari Undang-Undang Nomor 23 Tahun 2006 Pasal 13 ayat (3) tentang Administrasi Kependudukan. Pada pasal tersebut disebutkan bahwa setiap penduduk wajib memiliki NIK yang dicamtumkan dalam setiap dokumen kependudukan dan dijadikan dasar penerbitan Paspor, Surat Izin Mengemudi (SIM), Nomor Pokok Wajib Pajak (NPWP), Polis Asuaransi, Sertifikta Hak Atas Tanah dan penerbitan identitas lainnya. NIK bersifat unik dan tunggal yang diberikan kepada setiap penduduk dan berlaku seumur hidup. Oleh karna itu setiap penduduk memiliki NIK yang berbeda-beda.

Upaya untuk mendukung program pembuatan eKTP tersebut maka dibuatlah UU No. 25 Tahun 2009 Tentang Pelayanan Publik, sebagai acuan utama dalam memberikan 4 layanan publik. Dalam Undang-Undang ini, selain menjelaskan tentang apa itu pelayanan publik, juga menjelaskan tentang peran masyarakat dalam mengawasi dan mengawal pelayanan yang diberikan pemerintah.

Hal ini seperti yang tertuang pada Pasal 39, dimana dijelaskan bahwa peran serta masyarakat dalam pelayanan publik dimulai sejak penyusunan standar pelayanan sampai dengan evaluasi dan pemberian penghargaan, dengan demikian masyarakat juga memiliki peran serta dalam pemberian pelayanan publik, hal tersebut diwujudkan dalam bentuk kerja sama, pemenuhan hak dan kewajiban masyarakat, serta peran aktif dalam penyusunan kebijakan pelayanan public (Agus Dwiyanto. 2003)

Partisipasi masyarakat diperlukan untuk menjaga kualitas pelayanan publik. Pasalnya, masyarakat secara langsung menjadi pengguna dari lembaga pemerintahan yang memberikan pelayanan publik. Partisipasi masyarakat diantaranya bersinggungan dengan penyusunan kebijakan dan standar pelayanan publik. Serta, pengawasan dan evaluasi penyelenggaraan pelayanan publik. Peran masyarakat diharapakan mampu memberikan kontribusi dalam penyelenggaraan pelayanan publik agar terwujud pelayanan publik yang sesuai dan memberikan kemudahan bagi masyarakat.

Di Kota Makassar tepatnya di Kecamatan Kepulauan Sangkarrang partisipasi masyarakat dalam pembuatan e-KTP sangat penting karna seluruh penduduk di kecamatan ini tersebar dibeberapa pulau-pulau kecil yang berjauhan dengan ibu kota pemerintahan. Hal ini yang kemudian menjadi kendala yang dialami didalam proses pelayanan publik kepada masyarakat. Sebut saja misalnya transportasi masyarakat dari tempat kediamannya menuju kantor kelurahan semuanya menggunakan transportasi air seperti perahu dan kapal nelayan. Listrik yang seharusnya menyalah baik siang maupun malam harus dibatasi untuk malam saja demi untuk menghemat pengeluaran. Sementara kegiatan pemerintahan seharusnya dilakukan pada siang hari seperti didaerah-daerah lain pada umumnya. Hal ini bertujuan untuk menemukan masalah yang sesungguhnya sehingga ada alternatif solusi sebagai upaya penyeleseian masalah yang benar-benar dapat menjadi solusi jitu dalam hal urusan pembuatan e-KTP di kecamatan Kepulauan Sangkarrang. Karna itu peneliti mengangkat judul penelitian yaitu "Partisipasi masyarakat dalam mewujudkan e-KTP di Kecamatan Kepulauan Sangkarrang Kota Makassar. Adapun tujuan dari penelitian ini adalah sebagai berikut : Untuk mengetahui proses pengurusan pembuatan e-KTP di Kecamatan Kepulauan Sangkarrang Kota Makassar dan untuk mengetahui faktor yang mempengaruhi partisipasi masyarakat dalam mewujudkan e-KTP di Kecamatan Kepulauan Sangkarrang Kota Makassar.

\section{METODE}

\section{Jenis Penelitian}

Dalam penelitian ini penulis menggunakan pendekatan kualitatif. Menurut Bogdan dan Taylor dalam Moleong (2007:4) menyatakan bahwa penelitian kualitatif adalah sebagai prosedur penelitian yang menghasilkan data deskriptif berupa kata-kata tertulis atau lisan dari orang-orang dan perilaku yang diamati. Penelitian ini dipilih karena untuk menyajikan data secara sistematis, faktual, dan akurat mengenai fakta-fakta yang ada di lapangan. Dengan menggunakan desain penelitian deskriptif dengan pendekatan kualitatif bertujuan untuk menggali mengenai fakta mengenai parsipasi masyarakat kecamatan Kepulauan Sangkarrang dalam mendukung dan mewujudkan program e-KTP.

\section{Lokasi Penelitian}

Penelitian ini akan dilakukan di kecamatan Kepulauan Sangkarrang Kota Makassar. Adapun pelaksaan penelitian pada bulan Maret - April 2020. Kecamatan Kepulauan Sangkarrang dipilih karna kecamatan ini merupakan kecamatan yang ada dikota Makassar yang merupakan kecamatan dengan wilayah pemerintahannya terletak dibeberapa pulau diluar Makassar. Karna itu menarik untuk diteliti apakah selama pengurusan pembuatan e-KTPdi kecamatan ini berjalan dengan baik.

\section{Fokus dan Deskripsi Fokus}

Berdasarkan permasalahan-permasalahan terkait dengan upaya untuk mendorong partisipasi masyarakat kecamatan Kepulauan Sangkarrang dalam rangka mewujudkan program pembuatan e-KTP untuk seluruh penduduk terkhusus di kota Makassar. Adapun fokus penelitian ini adalah: 
1. Untuk mencermati seperti apa sistem dalam pembuatan e-KTP di kecamatan Kepulauan Sangkarrang sehingga masyarakat terdorong untuk terlibat aktif dalam pembuatan e-KTP. Adapaun indikator yang digunakan dalam rangka untuk membedah persoalan yang dimaksud yaitu landasan hukum yang digunakan, sosialisasi yang dilakukan selama ini dan kapasiatas dan sumber pendanaan yang cukup.

2. Untuk melihat faktor-faktor apa saja yang mempengaruhi dalam rangkah mendorong masyarakat Kepulauan Sangkarrang untuk berpartisipasi secara aktif dalam pembuatan e-KTP. Indikator yang digunakan dalam hal ini adalah komunikasi yang dilakukan selama in, ketersediaan sumber daya, sarana dan prasarana, dan kondisi geografis.

\section{Jenis dan Sumber Data}

Dalam rangka mendukung penentuan informan penelitian yang dianggap memiliki kapabilitas dan kredibilitas pada penelitian ini maka terlebih dahulu dipilih jenis data yang akan digunakan. Data yang digunakan dalam penelitian ini adalah:

\section{Data Primer}

Data primer adalah data yang diperoleh dengan teknik pengamatan langsung terhadap objek maupun wawancara lansung kepada para informan yang relevan dengan fokus penelitian. Menurut Arikunto (2010), data primer adalah data dalam bentuk verbal atau kata-kata yang diucapkan secara lisan, gerak-gerik atau perilaku yang dilakukan oleh subjek yang dapat dipercaya, yakni subjek penelitan atau informan yang berkenaan dengan variabel yang diteliti atau data yang diperoleh dari responden secara langsung. Sumber data primer pada penelitian ini terdiri dari :

a) Camat Kepulauan Sangkarrang (1 Orang)

b) Sekretaris kecamatan Kepulauan Sangkarrang (1 orang)

c) Pegawai Kependudukan di kecamatan Kepulauan Sangkarrang (1 Orang)

d) Kepala Kelurahan di kecamatan Kepulauan Sangkarrang (2 Orang)

e) Masyarakat di kecamatan Kepulauan Sangkarrang (3 Orang)

2. Data Sekunder

Data sekunder yaitu data yang diperoleh secara tidak langsung dari objeknyabaik secara lisan maupun tulisan. data yang diperoleh dari teknik pengumpulan data yang menunjang data primer. Menurut Arikunto (2010), data sekunder dalam sebuah penelitian diperoleh dari hasil observasi yang dilakukan oleh penulis serta dari studi pustaka. Data sekunder dapat berasal dari dokumendokumen grafis seperti tabel, catatan, chat, foto dan lainlain. Sumber data sekunder pada penelitian ini diperoleh dari :

a) Peraturan Perundang-Undangan:

b) Buku;

c) Penelusuran data online; d) Jurnal Ilmiah;

e) Dokumentasi.

\section{Teknik Analisis Data}

Proses analisis data dalam penelitian ini, pada hakekatnya dilakukan untuk menemukan sebuah pola, dengan cara mempelajari dan menelaah seluruh data yang tersedia. Data yang diperoleh dari berbagai sumber yaitu: pengamatan langsung, dan dokumen. Untuk menetapkan bagian-bagian, hubungan antar kajian dan hubungan terhadap keseluruhannya. Hakekatnya adalah untuk meningkatkan pemahaman terhadap semua hal yang dikumpulkan, yang selanjutnya menyajikan hasil kajian atau analisis data penelitian. Untuk melakukan proses analisis data menurut Milles dan Huberman dalam Sugiyono (2010:91) peneliti akan melakukan tiga tahapan proses, yaitu:

1. Tahapan reduksi data (data reduction). Data yang diperoleh dari lokasi penelitian (data lapangan) dituangkan dalam uraian atau laporan yang lengkap dan terinci. Laporan lapangan oleh peneliti akan direduksi, dirangkum, dipilih hal-hal yang pokok, difokuskan pada hal-hal yang penting kemudiaan dicari tema atau polanya (malalui proses penyuntingan, pemberian kode dan pentabelan). Reduksi data ini dilakukan secara terus menerus selama proses penelitian berlangsung.

2. Tahapan penyajian data (data display). Data dimasukkan untuk memudahkan peneliti dalam melihat gambaran secara keseluruhan atau bagianbagian tertentu dari penelitian. Dengan kata lain merupakan pengorganisasian data ke dalam bentuk tertentu sehingga kelihatan dengan sosoknya lebih utuh.

3. Tahapan penarikan kesimpulan atau verifikasi (conclusing drawing verivication). Dalam penelitian kualitatif, analisi data dilakukan secara terus menerus sepanjang proses penelitian berlangsung.

Sejak awal memasuki lapangan dan selama proses pengumpulan data, peneliti berusaha untuk menganalisis dan mencari makna dari data yang dikumpulkan yaitu dengan cara mencari pola, tema, hubungan persamaan, hal-hal yang sering timbul dan sebagainya yang dituangkan dalam kesimpulan yang masih bersifat tentative, akan tetapi dengan bertambahnya data melalui proses verifikasi secara terus menerus, maka akan diperoleh kesimpulan yang bersifat "grounded". Dengan kata lain setiap kesimpulan senantiasa terus dilakukan verifikasi salama penelitian berlangsung yang melibatkan interpretasi peneliti.

\section{HASIL DAN PEMBAHASAN}

Gambaran Umum Kecamatan Kepulauan Sangkarrang

Kecamatan Kepulauan Sangkarrang yang terletak dibagian utara yang merupakan satu dari lima belas Kecamatan yang ada di Makassar. Kecamatan Kepulauan Sangkarrang merupakan kecamatan termuda yang 
terbentuk pada tahun 2017 yang mempunyai visi : mewujudkan kecamatan kepulauan sangkarrang sebagai daerah wisata dan taman kehidupan bahari yang berkelanjutan yang dihuni masyarakat berwawasan bahari. Untuk mewujudkan visi tersebut maka misi kecamatan kepulauan sangkarrang yaitu:

1. Mewujudkan kecamatan kepulauan Sangkarrang sebagai kawasan wisata bahari unggulan di Sulawesi Selatan.

2. Meningkatkan profesionalisme aparatur pemerintah Kecamatan.

3. Mewujudkan pelayanan terpadu yang berkualitas.

4. Mewujudkan peningkatan kesejahteraan masyarakat melalui pemberdayaan masyarakat bahari.

5. Mewujudkan lingkungan fisik dan tata ruang yang mendukung pembangunan wisata bahari berkelanjutan.

Sedangkan penduduk Kecamatan Kepulauan Sangkarrang adalah 13.703 Jiwa yang terdiri dari 6.748 jiwa laki-laki dan 6.955 jiwa perempuan yang terbagi lagi dalam 3.451 KK dan 57 RT serta 15 RW. Mata pencaharian masyarakat umumnya adalah sebagai nelayan dan sebagian lagi sebagai pengrajin perahu. Kecamatan Kepulauan Sangkarrang terdiri dari 3 Kelurahan dengan luas wilayah 54,23 ha. Dari luas wilayah tersebut tercatat bahwa Kelurahan Barrang Lompo memiliki luas wilayah 19,23 ha, Kelurahan Barrang Caddi memiliki luas wilayah 38,19 ha yang terdiri dari 5 (lima) pulau yaitu pulau lumu-lumu, pulau lanjukang, pulau bone tambu, pulau langkai serta pulau barrang caddi itu sendiri, sedangkan Kelurahan terakhir yaitu Kelurahan Kodingareng memiliki luas wilayah 14 ha yang terdiri dari pulau kodingareng dan pulau kodingareng keke yang tak berpenghuni (BPS, 2019)

Mayoritas masyarakat Kecamatan Kepulauan Sangkarrang beragama Islam dengan memiliki fasilitas ibadah sebanyak 10 masjid dan 2 mushola yang tersebar di kelurahan kodingareng sebanyak 4, kelurahan barrang lompo sebanyak 2 dan kelurahan barrang caddi sebanyak 6 sarana ibadah. Sedangkan realisasi penerimaan pajak bumi dan bangunan sebanyak Rp. 57. 828.000,-- Yang terbagi menjadi Kelurahan Barrang Lompo penerimaan pajak bumi dan bangunan sebanyak Rp. 34.941.000,Kelurahan Barrang Caddi sebanyak Rp. 8.710.000,Kelurahan Kodingareng sebanyak Rp. 14.177.000,-. (Kecamatan Sangkarrang dalam Angka, 2019).

Letak dan status Kelurahan di Kecamatan Kepulauan Sangkarrang adalah pulau yang terdiri dari pantai dan memiliki ketinggian dari permukaan laut kurang dari $500 \mathrm{M}$. klasifikasi semua kelurahan yang ada di Kecamatan Kepulauan Sangkarrang adalah swasembada. Sedangkan fasilitas kesehatan yang ada sebanyak 2 Puskesmas dan 4 Puskesmas Pembantu terdiri dari Kelurahan Kodingareng sebanyak 1 Puskesmas, Kelurahan Barrang Lompo sebanyak 1 puskesmas dan yang terakhir Kelurahan Barrang Caddi sebanyak 4 Pustu (Kecamatan Sangkarrang dalam Angka, 2019).
Sistem Pembuatan e-KTP di Kecamatan Kepulauan Sangkarrang

Dalam perkembangan ilmu administrasi negara maka telah terjadi pergeseran titik tekan dari administration of public dimana negara sebagai agen tunggal implementasi fungsi negara atau pemerintahan kepada orientasi administrasi publik dimana negara atau pemerintah hanyalah sebagai fasilitator dan tidak lagi merupakan aktor utama atau sebagai driving forces (Utomo, 2012; 7). Sistem pelaksanaan administrasi yang baik ketika pelaksana dalam hal ini birokrasi berdimensi kerakyatan dalam perspektif yang lebih luas dan dalam, tidak hanya ditujukan untuk dan demi masyarakat (sebagai objek sekaligus subjek) tetapi membentuk masyarakat dimana masyarakat dapat meningkatkan kapasitasnya, masyarakat terlibat sebagai learning organization, dan ikut bertanggungjawab secara penuh dalam setiap kegiatan pemerintahan serta mampu memberdayakan dirinya (Utomo, 2012:16).

Berdasarkan Undang-Undang Nomor 23 Tahun 2006 sebagaimana telah diubah melalui Undang-Undang Nomor 24 Tahun 2013 tentang Administrasi Kependudukan bahwa pada dasarnya pembuatan e-KTP harus dilaksanakan sesuai dengan landasan hukum yang ada. Pada pembuatan e-KTP di kecamatan Kepulauan Sangkarrang dilaksanakan sesuai dengan peraturan perundangan yang berlaku. Dasar hukum yang digunakan adalah UU Nomor 23 Tahun 2006 tentang Administrasi Kependudukan, Peraturan Presiden Nomor 26 Tahun 2009 tentang Penerapan KTP Berbasis Nomor Induk Kependudukan Secara Nasioanal. Kemudian Peraturan Presiden Nomor 35 Tahun 2010 tentang Perubahan atas Peraturan Presiden Nomor 26 Tahun 2009. Selanjutnya dalam Permendagri Nomor 8 Tahun 2016 tentang perubahan kedua atas Permendagri Nomor 9 Tahun 2011 tentang Pedoman Penerbitan Kartu Tanda Penduduk Berbasis Nomor Induk Kependudukan Secara Nasional.

Beberapa hal prinsip dalam atauran tersebut termasuk diantaranya mengatur tentang standar oprsional prosedur (SOP) pada instansi yang menangai pembuatan e-KTP. Selain itu dalam regulasi tersebut juga diatur mengenai syarat dalam pembuatan e-KTP kepada setiap penduduka baik mereka yang abru akan dibuatkan KTPnya maupun yang akan mengganti KTPnya dengan alasan-alasan tertentu. Secara peraturan perundangundangan, pembuatan e-KTP di kecamatan Kepulauan Sangkarrang dijalankan secara konsekuan. Hal ini sesuai dengan konsepsi pelayanan publik (Batinggi; 2013) tentang prinsip-prinsip pelayanan yang baik dimana salah satunya harus memilki standar yang jelas.

Dalam pengamatan peneliti SOP dan persyaratan yang dibuat dalam rangka pelayanan pembuatan e-KTP di kecamatan Kepulauan Sangkarrang dilakukan sebagaimana mestinya. Hal ini dilakukan dalam rangka untuk membuat pelayanan tidak sulit dan berbelit-belit sehingga memudahkan masyarakat. Sekalipun sudah demikian pada kenyataannya masih banyak masyarakat 
yang merasa kesulitan dalam pembuatan e-KTP tersebut. Selaian itu, sosialisasi juga dilakukan agar masyarakat mudah memahami tentang proses pengurusan pembuatan KTP. Termasuk dalam hal ini adalah menyampaikan informasi kepada masyarakat bahwa mengurus KTP tidak mesti ke kota Makassar namun sudah bisa di kantor kecamatan. Dengan diberlakukannya kebijakan pengurusan KTP yang bisa dilayani di kantor kecamatan membuat masyarakat yang ada di kecamatan Kepulauan Sangkarrang semakin mudah untuk melakukan pengurusan.

Sosialisasi yang dilakukan tersebut melibatakan pemerintah kecamatan dan juga pemerintah kelurahan yang ada di kecamatan Kepulauan Sangkarrang. Juga yang menarik dalam hal sosialisasi ini adalah melibatkan pemuka-pemuka agama melalui informasi yang disampaikan di mesjid-mesjid oleh imam mesjid.

Informasi yang disampaikan kepada masyarakat dalam hal ini bukan hanya berkaiatan dengan tempat pelaksanaan perekaman KTP yang bisa dilakukan di kantor kecamatan. Namun hal lain yang dipertegas oleh aparat pemerintah didalam pesan isi sosialisasi tersebut adalah berkaiatan dengan prosedur dan persyaratan pembuatan KTP. Selama ini banyak masyarakat yang enggan mengurus untuk membuat KTP karna sering kali dipersulit bahkan tidak ada informasi jelas mengenai tata cara prosedur dalam pengurusan tersebut.

Kejelasan ini penting khususnya bagi masyarakat yang ada di kecamatan Kepulauan Sangkarrang mengingat masyarakat didaerah bertempat tinggal yang dipisahkan oleh pulau yang berbeda. Artinya kondisi mereka yang demikian sudah tentu menjadi soal apalagi ketika ditambah lagi dengan ketidakjelasan saat pengurusan sehingga mereka bisa saja sehari mengurus tidak selesai sehingga semakin membebani ongkos yang harus mereka keluarkan.

Selain itu dalam hal memperlancar proses pengurusan pembuatan e-KTP di kecamatan Kepulauan Sangkarrang, pendanaan juga menjadi hal yang penting. Sampai saat ketika penelitian ini dilakukan dilaporkan bahwa dana yang mereka gunakan dalam rangka mendukung pelaksanaan pembuatan e-KTP di kecamatan Kepulauan Sangkarrang bersumber dari dana dari Dukcapil itu sendiri kemudian ditambah dari dana oprasional dari pemerintah kecamatan. Hal dikarenakan pendanaan dari Dukcapil kota Makassar tidak dapat membiaya pengeluaran secara keseluruhan dalam rangka pelayanan pembuatan e-KTP di kecamatan Kepulauan Sangkarrang. Pembiayaan tersebut bukan hanya sebatas biaya perekaman dan percetakan yang selama ini dibiayai dari Dukcapil namun dalam hal pengobrasian alat tersebut harus membayar beban uang listrik tambahan.

Seperti yang peneliti ungkapkan sebelumnya bahwa salah satu kendala besar dalam pelayanan di kecamatan Kepulauan Sangkarrang adalah jaringan listrik. Didaerah ini listrik menyalah hanya pada malam hari dengan alasan mengirit biaya, sementara kegiatan pemerintahan dijalankan pada siang hari. Karna itu kantor kecamatan dalam setiap pelayanannya pada siang hari mengupayakan listrik secara mandiri melalui penyalaan generator. Daalam kondisi demikian yang dilakukan selama lima hari dalam satu minggu berdasarkan hari kerja kantor pemerintahan tentu akan sangat memberatkan bagi pemerintah kecamatan tersebut. Tidak heran beberapa kelurahan yang ada di kecamatan tersebut justru melakukan pelayanan kepada masyarakat dilakukan pada malam hari demi untuk meminimalisir pengeluaran.

Sementara itu dalam hal pembuatan e-KTP di kecamatan Kepulauan Sangkarrang tidak ada pungutan biaya sama sekali kepada masyarakat yang akan membuat KTP. Alasannya bahwa hal tersebut dilarang oleh Undang-undang dan juga jika itu dilakukan akan membuat masyarakat jadi tidak tertarik lagi untuk membuat KTP. Sedangkan mereka digratiskan dalam pembuatan KTP tersebut belum tentu mereka ikut berpatisipasi apalagi kalau harus dipertanggungkan biaya tambahan lagi.

Jadi secara keseluruhan pada aspek ini, bahwa sistem pengurusan pembuatan e-KTP di kecamatan Kepulauan Sangkarrang secara prosedur tidak ada yang bermasalah bahkan tidak membebani masyarakat sama sekali. Melaksanakan secara konsekuen dan juga kegiatan sosialisasi semuanya dilakukan secara baik. Hanya yang menjadi masalah pada aspek ini adalah sumber pendanaan dalam pembuatan e-KTP yang tidak semuanya ditanggung oleh Dukcapil sebagai dinas terkait. Namun masalah ini adalah masalah internal di kantor kecamatan Kepulauan Sangkarrang. Karna secara umum kepada masyarakat dalam hal pengurusan pembuatan e-KTP tidak ada yang dibebankan kepada mereka bahkan semuanya justru mempermudah masyarakat yang ada di kecamatan Kepulauan Sangkarrang.

Faktor yang Mempengaruhi Pembuatan e-KTP di kecamatan Kepulauan Sangkarrang

Salah satu faktor yang mempengaruhi pembuatan eKTP di kecamatan Kepulauan Sangkarrang adalah komunikasi. Kegiatan komunikasi dalam hal dilakukan dalam rangka untuk membangun keabraban antara masyarakat dengan pemerintah sehingga programprogram pemerintah dapat dijalankan dengan baik sebagaiman mestinya.

Di kecamatan Kepulauan Sangkarrang komunikasi antara pemerintah dengan masyarakat terjalin dengan sangat baik. Kegiatan komunikasi yang dilakukan adalah mendatangi warga masyarakat untuk menyampaikan halhal yang penting seputar dengan pembuatan e-KTP. Selain itu forum komunikasi masyarakat juga digalakkan dalam rangka membangun silaturahmi dan sinergi sehingga tidak ada ketimpangan dalam pelaksanaannya. Hal lain yang mempengaruhi pembuatan e-KTP di kecamatan Kepulauan Sangkarrang adalah ketersediaan sumber daya. Indikator sumber daya dalam hal ini diantaranya adalah pegawai (staf), ketersedian informasi dan kewenangan yang dimiliki oleh setiap penyelenggara.

Sumber daya pegawai yang bertugas untuk menyelenggarakan urusan pemerintahan di bidang 
pembuatan e-KTP di kecamatan Kepulauan Sangkarrang berjumlah dua orang yang berasal dari Dukcapil kota Makassar. Kedua staf ini adalah pegawai dari Dukcapil yang diperbantukan di kecamatan khusus untuk urusan pembuatan e-KTP.

Sampai sejauh ini tidak ada masalah berkaitan dengan jumlah pegawai yang ditugaskan di kecamatan Kepulauan Sangkarrang. Dua orang sudah dianggap cukup sesuai dengan beban kerja yang ada. Selaian dua orang pegawai tersebut sangat paham dengan tupoksinya dan juga mempunyai kemampuan yang cukup dalam rangka untuk mengoperasikan alat yang ada.

Ketersediaan sumber daya lainnya yaitu informasi yang cukup dan memadai justru menjadi salah satu masalah dalam rangka memperlancar urusan penyelenggaraan pemerintahan dalam hal ini pembuatan e-KTP di kecamatan Kepulauan Sangkarrang. Seperti yang peneliti telah singgung sebelumnya bahwa persoalan jaringan internet adalah salah satu masalah krusial yang ada di kecamatan Kepulauan Sangkarrang. Hal tersebut dikarenakan tidak setiap saat jaringan internet bagus karna layanan penyedia jasa internet didaerah ini masih terbatas selain itu kemampuan daya listrik juga terbatas.

Dalam kondisi demikian, informasi yang seharusnya di update oleh petugas dilapangan menjadi terkendala. Apalagi dalam zaman perkembangan sekarang dimana pemerintah sebagai intitusi yang bekerja untuk urusan public dituntut untuk menggunakan ilmu teknologi dan informasi dalam menyelenggarakan pelayanannya.

Selain itu kemampuan sumber daya juga ditopang oleh kewenangan yang diberikan kepada setiap pegawai yang bekerja sebagai implementator. Hal ini penting dalam rangka mempercepat penyeleseian masalah dilapangan serta tidak menunda jika ada hal-hal penting yang mendesak untuk diputuskan.

Dalam hal kewenangan yang dimilki oleh pegawai yang ditugaskan di kecamatan Kepulauan Sangkarrang dari Dukcapil kota Makassar cukup besar. Artinya bahwa mereka dilapangan dapat memutuskan hal-hal yang sifatnya teknis tanpa harus berkordinasi terelbih dahulu dengan pimpinannya. Urusan kordinasi baru dilakukan jika sudah menyangkut dengan kebijakan-kebijakan besar yang berkaitan dengan institusi secara keseluruhan.

Dalam banyak kesempatan pegawai Dukcapil yang ada di kecamatan Kepulauan Sangkarrang mengambil keputusan yang sifatnya teknis diantaranya mempersilakan masyarakat untuk membawa berkas permohonan pembuatan KTP ke kantor kecamatan sesudah itu dapat meninggalkan pengurusannya nanti pembuatannya selesai baru dikonfimasi kembali. Mereka mencatat secara detail dalam database bagi masyarakat yang mengurus KTP.

Faktor lainnya yang sangat berpengaruhi dalam pembuatan e-KTP di kecamatan Kepulauan Sangkarrang adalah ketersediaan sarana dan prasarana. dalam pembuatan e-KTP di kecamatan Kepulauan Sangkarrang relative cukup. Seperti gedung sebagai tempat perekaman, alat perekaman, komputer untuk menginput data dll sudah terpenuhi. Diluar gedung alat-alat tersebut semuanya berasal dari Dukcapil.

Kendala dilapangan untuk urusan pembuatan eKTP di kecamatan Kepulauan Sangkarrang tidak sebatas itu. Pasalnya pulau ini cukup jauh dari kota bahkan dibatasi oleh perbatasan laut sehingga jaringan listrik dan internet terbatas. Jaringan listrik dan internet sebagai kebutuhan utama dalam proses pelaksanaan kegiatan dilapangan oleh para pegawai. Karna jaringan listrik dan internet ini terbatas maka banyak pekerjaan pegawai dalam pembuatan KTP menjadi tertunda.

Sementara itu faktor lainnya yang sangat berpengaruh dalam pembuatan e-KTP di kecamatan Kepulauan Sangkarrang adalah kondisi geografis. Kecamatan Kepulauan Sangkarrang terdiri dari tiga kelurahan yaitu kelurahan Barrang lompo. Kelurahan Barrang Caddi dan Kelurahan Kodingareng. Batas-batas daerah kelurahan ini dibatasi oleh laut karna masing kelurahan terpisah diantara masing-masing pulau. Transportasi utama masyarakat adalah kapal, baik kapal nelayan maupun perahu-perahu kecil. Kondisi cuaca yang sering kurang bagus menjadi salah satu masalah yang sering dialami oleh masyarakat didaerah ini. Untuk datang kekantor kecamatan mereka harus menyeberang laut.

Secara umum urusan membuat KTP bukan hanya untuk kalangan pria saja tetapi juga perempuan,. Kondisi ini tentu menjadi masalah karna untuk sekedar datang kekantor kecamatan apalagi kalangan perempuan harus melewati laut yang sangat berisiko. Belum lagi ditambah dengan biaya perjalanan dengan menumpang ke kapal nelayan biayanya relative mahal. Itupun kalau pada saat mengurus KTPnya langsung jadi karna tidak ada masalah teknis seperti jaringan intenet dan listrik.

Secara keseluruhan, faktor yang berpengaruh secara signifikan dalam mendorong partisipasi masyarakat dalam pembuatan e-KTP di kecamatan Kepulauan Sangkarrang bukan faktor komunikasi dan juga sumber daya secara keseluruhan melainkan kondisi sarana dan prasarana terlebih khusus kondisi wilayah geografis masyarakat yang ada di kecamatan Kepulauan Sangkarrang.

Pada dasarnya masyarakat yang ada di kecamatan Kepulauan Sangkarrang ingin berpartisipasi secara keseluruhan dalam rangka membantu pemerintah dalam mewujudkan pembuatan e-KTP kepada semua penduduk. Selain itu tidak ada konflik antara masyarakat dengan pegawai sebagai penyelenggara, hal tersebut terlihat dengan sistem pembuatan e-KTP yang transparan dan tidak memungut biaya sama sekali dari masyarakat dalam pengurusan.

\section{KESIMPULAN DAN SARAN}

Kesimpulan hasil penelitian ini bahwa proses pengurusan pembuatan e-KTP di kecamatan Kepulauan Sangkarrang kota Makassar dilakukan dengan tiga konsep yaitu landasan hukum, sosialisasi, dan pendanaan. Faktor yang mempengaruhi pembuatan e-KTP di kecamatan 
Kepulauan Sangkarrang adalah komunikasi, sumber daya, sarana dan prasarana dan kondisi geografis. Dalam rangka peningkatan pelayanan e-KTP yang lebih baik salah satu yang harus menjadi perhatian oleh pemerintah dan semua stakeholder dalam hal ini adalah pendanaan Ketersedian sarana dan prasarana yang cukup juga harus didorong dan segera menjadi perhatian serius oleh pemerintah dalam rangka penyelesesian masalah tersebut.

\section{DAFTAR PUSTAKA}

Achyar, I. F., Juharni, J., \& Nurkaidah, N. (2019). Kualitas Pelayanan Dalam Sistem Penerbitan E-Ktp Pada Dinas Kependudukan Dan Pencatatan Sipil Kabupaten Maros. Jurnal Paradigma Administrasi Negara, 1(1), 27-31.

Adi, Isbandi Rukminto. 2007. Perencanaan partisipatoris berbasis aset komunitas: dari pemikiran menuju penerapan. Depok: FISIP UI Press.

Adisasmita, Raharjo. 2006. Pembangunan Pedesaan dan Perkotaan. Graha ilmu. Yogyakarta.

Agus Dwiyanto. 2003. Reformasi Tata Pemerintahan dan Otonomi Daerah. Yogyakarta: Pusat Studi Kependudukan dan Kebijakan UGM.

Arikunto, S. 2010. Prosedur Penelitian Suatu Pendekatan Praktik. Jakarta: Rineka Cipta.

Batinggi, A dan Badu Ahmad. 2013 Manajemen Pelayanan Publik. Yogyakarta: Andi Offset.

BPS, Kecamatan Kepulauan Sangkarrang dalam Angka Tahun 2019. Kota Makassar.

Moleong, Lexy J. 2007. Metodologi Penelitian Kualitatif. Edisi Revisi. Bandung : PT Remaja Rosdakarya.

Sugiyono. 2010. Metode Penelitian Pendidikan Pendekatan Kuantitatif, kualitatif, dan R\&D. Bandung: Alfabeta

UU No. 25 Tahun 2009 Tentang Pelayanan Publik

Undang-Undang No 23 Tahun 2006 dan Peraturan Presiden No 67 Tahun 2011 tentang Perubahan Kedua atas Peraturan Presiden No 35 Tahun 2010 tentang Penerapan KTP berbasis Nomor Induk Kependudukan.

Utomo, Warsito. 2012. Adminstrasi Publik Baru Indonesia; Perubahan Paradigma dari Adminstrasi Negara ke Adminstrasi Publik). Yogyakarta : Pustaka Pelajar. 